\title{
Description of Skrjabinodon spinosulus sp. n. (Nematoda, Oxyuroidea, Pharyngodonidae) from the Brazilian lizard Mabuya dorsivittata Cope, 1862 (Scincidae)
}

\author{
Joaquim Júlio Vicente ${ }^{1}$ \\ Davor Vrcibradic ${ }^{2}$ \\ Carlos Frederico D. Rocha ${ }^{2}$ \\ Roberto Magalhães Pinto ${ }^{1,3}$
}

\begin{abstract}
A new species of oxyurid, Skrjabinodon spinosulus, is described, on the basis of samples recovered from Mabuya dorsivittata Cope, 1862 in Brazil. Skrjabinodon spinosulus $\mathbf{s p .} \mathbf{n}$. is included in the group in which the males are provided with a spicule. The new species proposed herein, differs from those of the group, by the large number of spines (70-80) on the tail of the females when compared to those (3-48) in the other species. The number of spines is a character of great taxonomic importance in the specific diagnosis of these nematodes. This is the second report of the genus Skrjabinodon Inglis, 1968 in South America.

KEY WORDS. Nematode parasite, lizard parasite, oxyurid, Brazil
\end{abstract}

The present investigation adds new data to the previous surveys of nematode species parasitizing Brazilian reptiles (VICENTE et al. 1993a, 2000) and proposes a new species of nematode based on specimens recovered from a lizard.

\section{MATERIALS AND METHODS}

Twenty eight specimens of Mabuya dorsivittata Cope, 1862 were captured from January to December 2000. Sixteen lizards were obtained in the area of Prateleiras $\left(22^{\circ} 23^{\prime} S ; 4^{\circ} 40 \mathrm{~W}\right)$ in the Parque Nacional de Itatiaia, State of Rio de Janeiro and the other twelve lizards were from the Estação Ecológica de Itirapina ( $\left.22^{\circ} 15^{\prime} \mathrm{S} ; 47^{\circ} 49^{\prime} \mathrm{W}\right)$, State of São Paulo, Brazil.

Lizards were necropsied, helminths were recovered in a $0.85 \% \mathrm{NaCl}$ solution, fixed in hot $70^{\circ} \mathrm{GL}$ ethanol and processed for study as described elsewhere (VICENTE et al. 1993b). The preparation of en face glycerine-jelly mounts was in accordance with ANDERSON (1958). The ecological terms (prevalence, intensity and mean intensity) are used according to BUSH et al. (1997). Classification of the nematodes and host follows PetTer \& QUENTIN (1976) and PETERs \& DONOsoBARROS (1970), respectively.

1) Laboratório de Helmintos Parasitos de Vertebrados, Departamento de Helmintologia, Instituto Oswaldo Cruz. Avenida Brasil 4365, 21045-900 Rio de Janeiro, Rio de Janeiro, Brasil.

2) Setor de Ecologia, Instituto de Biologia, Universidade do Estado do Rio de Janeiro. Rua São Francisco Xavier 524, 20550-011 Rio de Janeiro, Rio de Janeiro, Brasil.

3) CNPq research fellow. Corresponding author. E-mail: rmpinto@ioc.fiocruz.br 
Figures were made with a drawing tube connected to a Olympus brightfield microscope. Photomicrographs were derived from a Axiophot microphotograph system (Zeiss, Germany) using a T400 CN film (Kodak, Mexico) in Differential Interference Contrast (DIC) apparatus. Measurements are in micrometers $(\mu \mathrm{m})$ unless otherwise indicated. Means are in parentheses.

The specimens studied were deposited in the Helminthological Collection of the Oswaldo Cruz Institute (CHIOC).

\section{RESULTS}

Eight animals from Itatiaia, out of the nine positive lizards, were parasitized with $S$. spinosulus $\mathbf{s p .} \mathbf{n}$. in association with the nematode Physaloptera retusa Rudolphi, 1819 and one had only the new species. Two lizards from Itirapina, were positive for nematodes: one with 33 of $S$. spinosulus $\mathbf{s p .} \mathbf{n}$. and another with $P$. retusa only. For $S$. spinosulus sp. n. recovered from lizards captured in Itatiaia, the prevalence, range of infection and mean intensity were of $56.25 \%, 1-9$ and $2.6( \pm$ 2.6), respectively.

\section{Skrjabinodon spinosulus sp. $\mathbf{n}$.}

Figs 1-7

Description and measurements based on eight adult specimens, three males and five females (mounted in toto).

Males (Figs 3, 4). Small, withe nematodes 1.47-1.72 (1.57) mm long, 140-150 (140) wide, with cylindrical body and tapered extremity. Cuticle with transverse striations. Mouth circular, surrounded by three small lips, each with an outer small papilla, two larger ones in the inner circle and an intermediate pair of amphids (Fig. 3). Lateral alae absent. Length of esophagus 180-200 (190); esophageal bulb 39-60 (40) long, 50-72 (60) wide. Excretory pore not observed. Nerve ring 43-50 (40) from anterior end. Tail 140-180 (160) long, smooth, conical. Caudal alae absent. Three pairs of sessile caudal papillae; one pair precloacal, one pair postcloacal and the third pair lies near the base of the tail. Spicule single, $43-50$ (40) long. Gubernaculum absent. Cloacal aperture 180-230 (200) from posterior extremity.

Females (Figs 1, 2, 5-7). Body 7.44-8.96 (8.21) mm long, 140-150 (140) wide. Mouth as described for the males. Lateral alae absent. Length of esophagus 410-430 (420); esophageal bulb 75-100 (90) long, 90-130 (100) wide. Excretory pore and nerve ring 300-560 (400) and 100-130 (110) from anterior end, respectively. Vulvar aperture in the post esophageal region, opening posteriorly to the excretory pore, at 370-600 (460) from the anterior extremity. Vagina muscular, directed posteriorly. Uteri opposed. Tail 450- 630 (520) long, filiform, covered with at least 70-80 cuticular spines distributed from the base of the tail and occupying 2/3 of its length (Figs 2, 5, 6). Eggs 160-180 (160) long, 36-50 (60) wide, with an inconspicuous plug at each end and slightly flattened on one side (Fig. 7). Anus1.75$1.89(1.80) \mathrm{mm}$ from the posterior extremity.

Type host. Mabuya dorsivittata Cope, 1862, distributed in Brazil (centralwestern, southeastern and southern regions), Bolivia, Uruguay and north Argentina. 

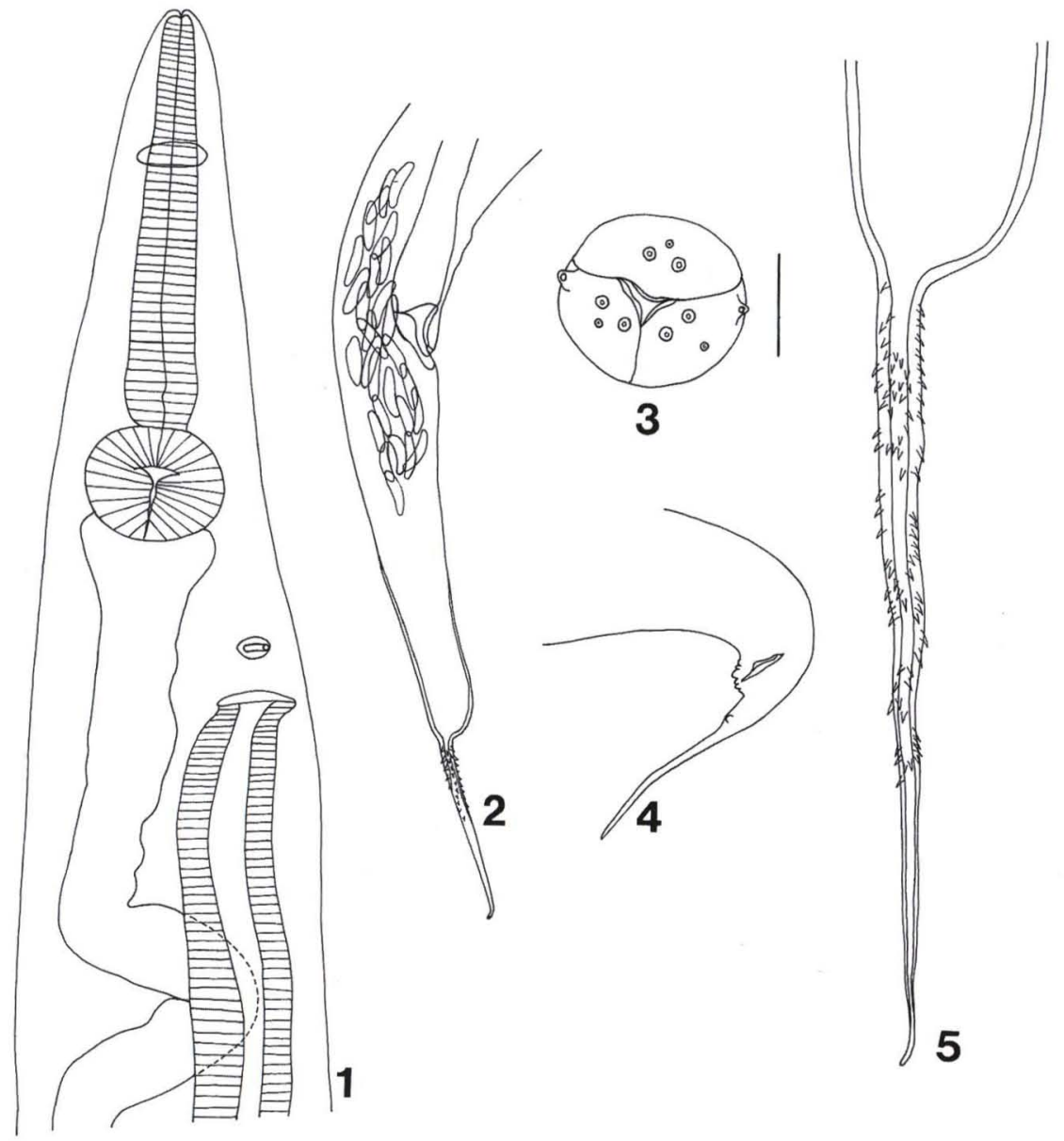

Figs 1-5. Skrjabinodon spinosulus sp. $\mathrm{n}$. (1) Anterior portion of female, lateral view (Bar $=0.1$ $\mathrm{mm})$; (2) posterior portion of female, lateral view $(B a r=0.3 \mathrm{~mm})$; (3) cephalic extremity of male, en face view (Bar $=0.05 \mathrm{~mm}$ ); (4) posterior extremity of male, lateral view (Bar $=0.05 \mathrm{~mm})$; (5) tail of female, showing the distribution of spines, lateral view $(B a r=0.1 \mathrm{~mm})$. Bar of figure 3 common to figures $1,2,4,5$.

Site of infection. Small and large intestine.

Type locality. Prateleiras, Parque Nacional do Itatiaia, State of Rio de Janeiro, Brazil.

Other locality. Estação Ecológica de Itirapina, State of São Paulo, Brazil.

Specimens deposited: CHIOC no. 34539 a (alotype), b-c (paratypes), 34540 a-b (paratypes), 34541 a-f (paratypes) - whole mounts.

Etymology. The specific name derives from the Latin, meaning "quite spiny".

This is the first report of helminths parasitizing specimens of $M$. dorsivittata. 

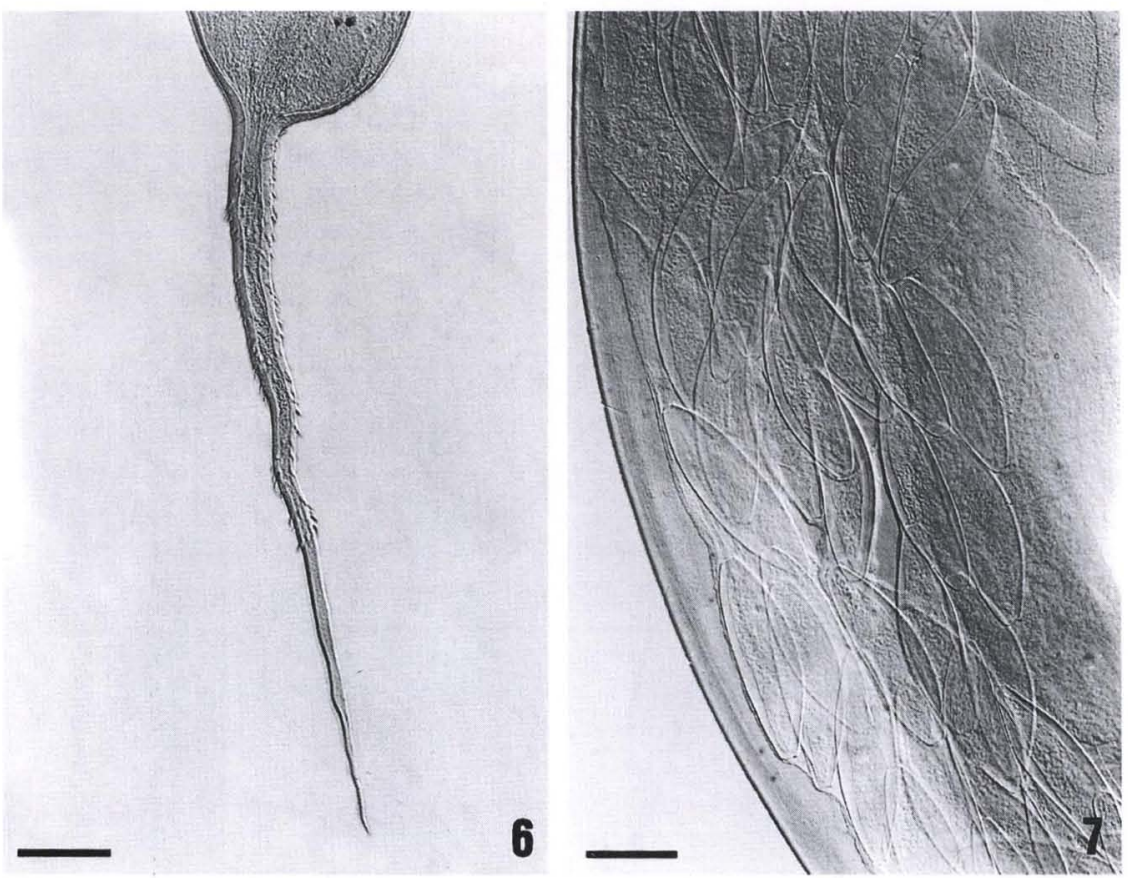

Fig 6-7. Skrjabinodon spinosulus sp. $n$. (6) Tail of female, showing the cuticular spines, lateral view $($ Bar $=0.1 \mathrm{~mm}) ;(7)$ eggs in utero $($ Bar $=0.05 \mathrm{~mm})$.

Remarks. In the genus Skrjabinodon Inglis, 1968, there are 16 species in which the spicule is present: S. mabuyae (Sandground, 1936), S. scelopori (Caballero, 1938), S. oedurae (Johnston \& Mawson, 1947), S. parasmithi Mawson, 1969 (erroneously referred to as $S$. parasmithy Mawson, 1971 by MORAVEC \& BARUS (1990), S. cricosaurae Barus \& Coy-Otero, 1974, S. medinae (Garcia-Calvente, 1948) Specian \& Ubelaker, 1974, S. schikhobalovi (Annaev, 1973), S. mascomai Roca, 1985, S. canariensis (Solera-Puertas, Zapatero-Ramos, Castaño-Fernandez \& Carrera-Moro, 1987) Moravec \& Barus, 1990, S. aegyptiacus (Moravec, Barus \& Rysavy, 1987) Moravec \& Barus, 1990, S. hemidactyli Moravec \& Barus, 1990 (MORAVEC \& BARUS 1990), S. poicilandri Ainsworth, 1990, S. trimorphi Ainsworth, 1990 (AINSWORTH 1990). Later, another three species were reported: S. alcaraziensis Lafuente \& Roca, 1995 (LAFUENTE \& RoCA 1995), S. azerbajdzanicus (Sharpilo, 1974) Bursey \& Goldberg, 1999 and S. piankai Bursey \& Goldberg, 1999 (BURSEY \& GOLDBERG 1999a, b).

Females of the different species of Skrjabinodon, no matter the presence or absence of the spicules in the males, present cuticular spines along the tail (except for S. mascomai and S. shikhobalovi [with males unknown] in which the tail is spineless) and their number varies according to the species. Therefore, this character is important and reliable in the specific diagnosis and has been previously considered (BURSEY \& GOLDBERG 1999b). 
Skrjabinodon spinosulus $\mathbf{s p .} \mathbf{n}$. is easily distiguished from the above referred species by the large number of caudal spines (at least 70), when compared to the small numbers seen in females of $S$. azerbajdzanicus (3), S. cricosaurae (3-7), $S$. medinae (3-7), S. hemidactyli (4) and S. piankai (4-7).

In $S$. parasmithi, spines are referred to as few, thin and pointed. More caudal spines have been reported in females of S. alcaraziensis (9), S. scelopori (10-12), S. trimorphi (16-24), S. oedurae (19) and $S$. poicilandri (3 long basal spines plus an additional 36-44 distributed along the tail). These differ significantly from $S$. spinosulus sp. $\mathbf{n}$., since the ratio between the number of caudal spines in the new species and the largest number previously reported is of 1:0.58, whereas considering the smallest number of spines, this ratio is of 1:0.05.

When only males are found, the length of the spicule, in association with other morphometric data, is a useful comparative character for specific identification. This procedure must also be used in the case of $S$. mabuyae and $S$. aegyptiacus, in which females are unknown, and S. canariensis with females having "numerous" (not specified) caudal spines. In this case, however, males have a post-anal lobe, similar to a papilla, which is not present in $S$. spinosulus $\mathbf{s p .} \mathbf{n}$.

\begin{abstract}
ACKNOWLEDGEMENTS. To Dr. Charles R. Bursey, Pennsylvania State University, USA, for the supply of reprints and for the translation of a Russian text, to Setor de Multimeios/IOC, to Heloisa Diniz, Laboratório de Produção e Processamento de Imagens/IOC for technical assistance regarding photomicrographs presented, and to Mara C. Kiefer, Luciano A. dos Anjos and Márcio Martins for supplying the specimens of Mabuya dorsivittata collected by them in the course of their project "Diversidade de Vertebrados Terrestres da Estação Ecológica de Itirapina, SP.”. This study was partially supported by grants from the Fundação de Amparo à Pesquisa do Estado do Rio de Janeiro - FAPERJ (Proc. E-26/170.385/97-APQ1) and from the Conselho Nacional de Desenvolvimento Científico e Tecnológico-CNPq to the second author (Proc. no. 143607/98-7) and to the third author (Proc. no. 400115/97-2 and 300819/94-3).
\end{abstract}

\title{
REFERENCES
}

AINSWORTH, R. 1990. Male dimorphism in two new species of nematode (Pharyngodonidae: Oxyurida) from New Zealand lizards. Jour. Parasitol. 76: 812-822.

Anderson, R.C. 1958. Méthod pour l'examen des nématodes en vue apicale. Ann. Parasitol. 33: 171-172.

BurSEy, C.R. \& S.R. GoldberG. 1999a. Spaulingodon ovifilus n. sp. (Nematoda: Pharyngodonidae) and other helminths from Diplodactylus stenodactylus (Reptilia: Gekkonidae) from Australia. Jour. Parasitol. 85: 898-902.

— 1999b. Skrjabinodon piankai sp. n.. (Nematoda: Pharyngodonidae) and other helminths of geckos (Sauria: Gekonidae: Nephrurus spp. from Australia. Jour. Helmithol. Soc. Wash. 66: 175-179.

Bush, A.O.; K.D. LAFFERTY; J.M. Lots \& A.W. ShostaK. 1997. Parasitology meets ecology on its own terms: Margolis et al. revisited. Jour. Parasitol. 83: 575-583.

LAFUente, M. \& V. RocA. 1995. Description of Skrjabinodon alcaraziensis sp. n. (Nematoda: Pharyngodonidae), a parasite of Algyroides marchi (Sauria: Lacertidae). Folia Parasitol. 42: 130-134. 
MoraVeC, F. \& V. BARUS. 1990. Some nematode parasites from amphibians and reptiles from Zambia and Uganda. Acta Soc. Zool. Bohemoslov 54: 177-192.

Peters, J.A. \& R. Donoso-Barros. 1970. Catalogue of the neotropical Squamata: Part II. Lizards and Amphisbaenians. US Nat. Mus. Bull. 297: 1-293.

PetTer, A. J. \& J.C. Quentin. 1976. Key to the genera of Oxyuroidea, p. 1-30. In: R. C. Anderson, A. G. Chabaud, S. Willmot (Eds), Keys to the Nematode Parasites of Vertebrates 4. England, Commonwealth Agricultural Bureaux, 30p.

Vicente, J.J.; D. VRCibradic; L.C. Muniz-Pereira \& R.M. Pinto. 2000. Skrjabinodon heliocostai sp. n. (Nematoda, Pharyngodonidae) parasitizing Mabuya frenata (Cope) (Lacertilia, Scincidae) in Brazil and the reallocation of Skrjabinodon capacyupanquii (Freitas, Vicente \& Ibañez) in the genus Thelandros Wedl. Revta bras. Zool. 17: 361-367.

Vicente, J.J.; H.O. Rodrigues; D.C. Gomes \& R.M. Pinto. 1993a. Nematóides do Brasil. Parte III: nematóides de répteis. Revta bras. Zool. 10: 19-168.

Vicente, J.J.; R.M. Pinto \& D. Noronha. 1993b. Remarks on six species of heterakid nematodes parasites of Brazilian tinamid birds with a description of a new species. Mem. Inst. Oswaldo Cruz 88: 271-278.

Recebido em 20.VII.2001; aceito em 14.II.2002. 